\title{
Policies on Regulatory Reform in Indonesia: Some Proposals
}

\section{Ibnu Sina Chandranegara', Muhammad Ali $^{2}$}

${ }^{1}$ Faculty of Law, Universitas Muhammadiyah Jakarta, Indonesia. E-mail : ibnusinach@umj.ac.id ${ }^{2}$ Faculty of Law, Universitas Muhammadiyah Jakarta, Indonesia. E-mail : muhali.6119@gmail.com

\begin{tabular}{l} 
ARTICLE INFO \\
\hline Keywords: \\
simplification regulations; \\
harmonization; legislation \\
How to cite: \\
Chandranegara, I.S. E Ali, \\
M. (2020). Policies on \\
Regulatory Reform in \\
Indonesia: Some Proposals. \\
JURNAL MEDIA \\
HUKUM, 27(1), 55-67. \\
Article History: \\
Received: 25-02-2020 \\
Reviewed: 08-06-2020 \\
Revised: 15-06-2020 \\
Accepted: 24-06-2020
\end{tabular}

\begin{abstract}
After the reformation, the number of laws and regulations has continued to increase. In the period 2000-2017, there were 35,901 regulations have been issued. The highest number is Regional Regulations, which are as many as 14,225 Regional Regulations, followed by a Ministerial Regulation at 11,873. In the third place, there were 3,163 regulations from non-ministerial institutions. This study has main objectives of finding policy choices in an effort to simplify and identify regulations as an agenda for legal reform. This research is a normative juridical research. The data used are secondary data, which includes primary and secondary legal materials, in the form of relevant legislation, as examples of regulations that are out of sync, incoherent, and potentially overlapping. This study concluded that the regulatory reform agenda can be carried out by three means, i.e. (1) Regulatory simplification (2) Reconceptualization of understanding regulatory needs and (3) synergies between regulators. There must be also some reformation between actual practice and long term frameworks on regulation making process and regulation itself. That is because effective regulation is not just predicated on technical information-capturing capabilities (and the experience) of the regulator.
\end{abstract}

DOI: 10.18196/jmh.20200142

Copyright (C) 2020 MEDIA HUKUM. All rights reserved.

\section{Introduction}

Indonesia has a high number of overlapping or contradictory laws and regulations. This condition is well known as hyper-regulation crisis. ${ }^{1}$ After a political transition from the authoritarianism regime to the democratic era in 1998, number of laws and regulations has continued to increase. From 2000 up until in the late 2017, there were 35.901 regulations, the highest number was Regional Regulations, which was 14.225 regulations, followed by Ministerial Regulations with 11.873 regulations, and in

\footnotetext{
${ }^{1}$ Susskind said that "By that I meant we are all governed today by a body of rules and laws that are so complex and so large in extent that no one can pretend to have mastery of them all. I argued then that hyper-regulation means not that there is too much law, by some objective standard, but that there is too much law given our current methods of managing it." Susskind, R. (2010). Legal Informatics: a Personal Appraisal of Context and Progress. European Journal of Law and Technology, 1 (1), p. 90-92.
} 
third place was Non-Ministerial Regulations with 3.163 regulations. ${ }^{2}$ There are still 36 Dutch colonial legacy regulations. ${ }^{3}$ This quantity does not accord with the quality of regulation. Until March 2017, there were 802 Constitutional Court decisions, and 203 Supreme Court decisions and this number still increasing. ${ }^{4}$ Another problem is the amount of regulation database that is not the same between one data manager and another data manager. Until now there has not been an institution that is the sole manager of official statutory data. To that end, the Government will cut 100 rules every month and draft an Omnibus Law to facilitate business licensing. In addition, the Government is also preparing Regulatory Technology (Reg Tech). ${ }^{5}$

Besides, fiscal decentralization and regional autonomy are often blamed by entrepreneurs and potential investors as the 'culprits' of a high-cost economy that results in an uncompetitive business climate in Indonesia and low new investment. A number of regional legal products issued by the Regional Government during the course of regional autonomy are considered by businesses to be burdensome to the business world and not in favor of the investment climate. Policies in the form of regional taxes and regional levies that are not pro-business are considered as reasons why investors are reluctant to invest in the area. The accusation is not entirely wrong given the low rate of investment growth in the early days of the implementation of decentralization which coincided with the end of the economic crisis. The accusation was reinforced by the fact that in those times many regional regulations appeared that were "strange" and clearly contradicted the principle of economic competitiveness. According to the Indonesian Chamber of Commerce and Industry, 5 (five) main problems facing the business world in Indonesia are: first, taxation, second, legal certainty and law enforcement, third, employment, fourth, physical infrastructure, and fifth, regional autonomy. The large amount of levies in the form of local taxes and regional levies will cause a high cost economy, marginal cost of production will be expensive, because the size of the levies will be calculated by employers as production costs, the product output offered to the market will be expensive compared with similar products, so that these products do not have good competitiveness in the market. ${ }^{6}$

Regulatory reform measures were often the response to significant political and economic changes such as the (i) Asian financial crisis, (ii) the downfall of Suharto, (iii) decentralization, and (iv) economic pressures in a globalized and competitive world. ${ }^{7}$ The Asian financial crisis proved to be an economic and political catalyst. The social costs of the crisis contributed to the dissolution of the new order government under Suharto. However, much of this recovery would not have happened if Indonesia had

${ }^{2}$ Chandranegara, I.S. (2017). Menemukan Formulasi Diet Regulasi. National Conference of Constitutional and Administrative Law Academician, p. 208-211.

${ }^{3}$ Hartono, S. (2014). Analisis dan Evaluasi Peraturan Kolonial (Masa Hindia Belanda dan Kependudukan Jepang). Badan Pembinaan Hukum Nasional, 2017, p. 22-23.

${ }^{4}$ Chandranegara, I.S. (2019). Kemerdekaan Kekuasaan Kehakiman Pasca Transisi Politik. Radjawali Press, p. 112.

${ }^{5}$ Setiadi. W.(2020). Simplifikasi Regulasi Melalui Pendekatan Omnibus Law: Suatu Keniscayaan. Studium Generale on Dies Natalis Universitas Pembangunan Nasional "Veteran" Jakarta, p. 2.

6 Redi, A \& Chandranegara, I.S (2020). Omnibus Law: Diskursus Pengadopsiannya Ke Dalam Sistem Perundang-Undangan Nasional. Radjawali Press, p. vix.

${ }^{7}$ Heilmann, D., Ekatjahjana, W. \& Hauerstein, K. (2019). Regulatory Reform in Indonesia A Legal Perspective. Hanns Seidel Foundation Cooperation with The Ministry of Law and Human Rights Directorate General of Legislation, p 5-7. 
not reformed its banking sector, liberalized to (a certain extent) its markets and attracted Foreign Direct Investment, regulated anti-competitive conduct, and introduced its first policies for regulatory reform and deregulation packages. ${ }^{8}$ The growing importance of reform if or in Indonesia's regulatory framework is to a large extent the result of Indonesia's system transition from a centralized and authoritarian state, to liberal democracy. The other catalyst for reform was the rapid decentralization process and the transfer of the majority of legislative and administrative powers to sub-national level, starting in 1999. Significant law-making powers have been devolved to Indonesia's districts and provinces which now include 1000 local legislating bodies and executive officials, such as mayors, regents, and governors, issuing local regulations and administrative decisions. The combined sound output of these lawmakers has added great bulk, complexity, and uncertainty to Indonesia's legal system. Many new local laws have been criticized for being misdirected or unclear, violating citizens' rights, imposing excessive taxes, even breaching Indonesia's international obligations. ${ }^{9}$ As a result, the national government tried to regain much of its legislative powers which granted them the authority to extensively review, sanction, and even trump local regulations which conflict with high ranking legislative instruments. It has done so with regards to local regulations related taxes and user charges. However, with the reform of radical decentralization initiated in 1999, the genie was out of the bottle. ${ }^{10}$ Thousands of sub-national legal instruments have been issued and only in parts have been reviewed. Until today, Central Government was not able to establish an effective review mechanism. Besides those local legislations, which have been submitted for review, there are still thousands, which are undetected, or which are still on the books, even though they have been invalidated. Besides, to the devolution of legislative powers, most of the administrative powers, i.e., the implementation of national law as well as the provision of public services, have been transferred to the sub-national level. This leads to other problems, as processing time and costs for issuing licenses largely vary throughout the archipelago, increasing administrative costs for business as well citizens. ${ }^{11}$

This fact shows that the regulation in Indonesia still not well planned. If this problem is not immediately resolved, it will be resulting in ineffective administration, lengthy processes, and obstacles for economic development. ${ }^{12}$ While the Government has taken several measures to enhance regulatory reform, regulatory functions are currently scattered across several governmental institutions, making a web of uncoordinated mandates. $^{13}$

This study has the objective to find out policy options to simplify and restructure the regulatory system as the main agenda for regulatory reform in Indonesia.

\footnotetext{
${ }^{8}$ Chandranegara, I.S. (2016). Purifikasi Konstitusional Sumber Daya Air Indonesia. Rechtsvinding, 5 (3), p. 359-379.

${ }^{9}$ Ibid.

${ }^{10}$ Ibid, p 10.

11 Ibid.

12 Malau, M. T. (2014). Legal Aspects of Government Regulations and Policies Facing Regional Economic Liberalization: ASEAN Economic Community 2015. Rechtsvinding, 3 (2), p. 163-182.

13 Hartono, D. \& Hardiwinoto, S. (2018). Legal Perspective on Asean Economic Community. Diponegoro Law Rev, 3 (2), p. 199-222.
} 


\section{Method}

This research is a normative juridical research. The data used are secondary data that includes primary and secondary legal materials in the form of relevant laws and regulations used as samples of regulations that are out of sync, incoherent, and potentially overlapping especially on economic sector. Secondary data obtained through literature study. The method used is the conceptual approach and the statue approach. Data analysis is done by systematizing data so that the data is then used to propose the best concept in an effort to simplify and harmonize regulations.

\section{Analysis and Results}

\subsection{Simplification}

Simplification is the first policy on regulatory reform that could be used in Indonesia to decrease the quantity of regulations. Simplification method will be conducted by collecting existing regulations, identifying problems and stakeholders, evaluating problematic regulations, and removing unnecessary regulations. ${ }^{14}$ The efforts of the Ministry of Law and Human Rights to provide a directory of regulations in mapping regulatory formation subsequently enters the stage of simplification of regulations in certain aspects to ensure legal certainty. Furthermore, the stages of regulation implementation begin in the sequence of the process, starting with collection of the relevant regulations, then identification, analysis, and then recommendations. From this process, it could be seen whether a regulation can be maintained or harmonized or it must be revoked immediately. Recommendations can also include proposals for making new regulations if needed.$^{15}$ Because of the large number of regulations, the simplification of regulations must be mass and fast, so that it is necessary to formulate simple criteria in carrying out these simplification stages.

The first criteria would be conflicted regulation, where there are articles or provisions that clearly contradict other regulations. For example, Art 29 (2) and (3) Agrarian Act of 1960 regulates that the right to cultivate can be granted for a maximum period of 60 years is regarded in contravention with Art 22 (1) Investment Act of 2007 which regulates that the rights to cultivate can be granted for a maximum period of 95 years, and Art 35 (1) and (2) Agrarian Act of 1960 which regulating that the rights to build can be granted for a maximum period of 50 years with Art 22 (1) point b of the Investment Act of 2007 which stipulates that the rights to build can be granted for a maximum period of 80 years. Even though some opinions said that as far as matter of right of land is concerned, Law on Agraria prevails than other laws, the conflicted regulation is created uncertainty.

The second criteria will be inconsistent regulations. This means that there is no consistency concerning a specific or certain issue in one and another sectoral laws and its implementation into regulation. For example, the inconsistent definition of investment between Investment Act of 2007 and Government Regulation No 1 of 2007 jo. Government Regulation No. 62 of 2008 concerning Income Tax Facilities for Investments in Certain Business Fields and/or in Certain Regions. Under Investment

\footnotetext{
${ }^{14}$ Sadiawati, D. (2015). Strategi Nasional Reformasi Regulasi: Mewujudkan Regulasi yang Tertib dan Sederhana. Kementerian Perencanaan dan Pembangunan Nasional/ Bappenas, p. 34.

${ }^{15}$ Anggono, B.D. (2014). Perkembangan Pembentukan Undang-Undang di Indonesia. Konstitusi Press, p. 88.
} 
Act, Investment defined as all forms of Investment activities, both by domestic investors and foreign investors to do business in the territory of the Republic of Indonesiaz and but its it different under Government regulation which stipulated that Investments are investments in the form of tangible fixed assets including land property used for main business activities, both for new investments and expansion of existing businesses.

The third criteria is the regulation that creating multiple interpretations. This type of criteria is lack of clarity on the object and the subject on the regulation and difficult to understand. For example, Art 14 Investment Act of 2007 states: "Every investor is entitled to: a. certainty, legal protection; b. etc..." The elucidation states that "What is meant by 'certainty of rights' is the Government guarantee for investors to obtain rights as long as the investor has carried out the specified obligations." The norm and its explanation do not answer what rights that are guaranteed. So, this kind of norm has a lack of clarity.

The fourth criteria is difficult to implement. Certain regulation is declared difficult to implement, but the regulation is still valid, or the regulation does not have implementing regulation yet. By analyzing these four criteria, there are some condition that certain regulation can still be maintained if (1) the regulation does not have any potential conflict with other regulations, especially to the legislation, (2) the regulation is needed by public or by state administrators, and (3) the regulation is businessfriendly. The recommendations after analyzing criteria and problem cluster determine further actions that must be taken. If the recommendation is for regulations to be maintained, then follow-up is no longer needed. If the recommendation is that the regulation should be revised or revoked, then the necessary follow-up is to take the steps as regulated in Law and Regulation Procedure Act of 2011.

\subsection{Reconceptualization of Rule Making Power}

On many occasions, President Joko Widodo often complained about the number of laws. He argues if good-quality law is made simply, three or five laws are enough in one year. ${ }^{16}$ Despite hyper-regulation scattered in the Indonesian legal system, Saldi Isra explained the current quantity of laws could not be qualified as bad or worse. There are many laws based on the mandate of the 1945 Constitution that has not yet been implemented, and in other conditions there are many sectoral problems that require regulatory updates. ${ }^{17}$ For example, revision of Regional Government Act of 2004 into Regional Government Act of 2014 where the new law that is related to many other (sectoral) laws will cause an adjustment to those laws especially related to the new regional governance. ${ }^{18}$ Maria Farida Indrati argued that a lot of content that should have been sufficiently regulated through law. ${ }^{19}$

According to some analysis above, the main focus for resolving the hyper-regulation problem lies in the reconceptualization rule-making power on laws and regulations. According to Art 7 (1) Law and Regulation Procedure Act of 2011 the main problem comes from government regulations and presidential regulations. Art 12 and 13 Law

\footnotetext{
${ }^{16}$ Isra, S. (2017). Merampingkan Regulasi. Kompas, March 13th 2017,

${ }^{17} \mathrm{Ibid}$

${ }^{18}$ Djamil. N, (2015). Setengah Hati Reformasi Regulasi. Seputar Indonesia, November 12th, 2015.

19

Indrati, M. F. (2008). Kompendium Ilmu Perundang-undangan. Kementeriaan Hukum dan HAM, p. 44
} 
and Regulation Procedure Act of 2011 confirm that subject matter Government Regulations is for the implementation of the Law. Presidential Regulation must be ordered by law, and implementing government regulations or implementing executive administration according to Art 4 of the 1945 Constitution. This situation brings the conclusion that the administration of government will rely on government regulations and Presidential regulation. This construction puts Government Regulations or Presidential Regulation reflecting the real legal policy rather than the Law. Additionally, the formulation of Government Regulations and Presidential Regulation must be planned and not reactive. For example, Presidential Regulation No. 36 of 2005 concerning Land Procurement for Development is known as a follow up to the 2005 Infrastructure Summit. The Presidential Regulation was rejected by most of people with a wave of massive demonstration. The Presidential Regulation was later changed into Presidential Regulation No. 65 of 2006, which in fact is not much different in substance from the previous one. Another example is the issuance of the Minister of Maritime Affairs and Fisheries Regulation No. 2 of 2015 concerning the prohibition of fishing using cantrang fishing gear. These tools are not considered environmentally friendly. However, Luhut Binsar Panjaitan, as the Coordinating Minister for Maritime Affairs, wanted to maximize the fishing capability of the fishermen. Therefore, the Ministerial Regulation was requested to be revoked.

Based on situation above, there were two solutions for limiting the will for making regulation. First, limiting authority of rule-making power, especially ministerial regulations, by eliminating the phrase "form based on the power" as stipulated in Art 8 (2) Law and Regulation Procedure Act of 2011. Second, even though the rule-making power presented by the delegation concept, the authority must be supported by an obligation that every Ministerial Regulation draft must follow the harmonization process in the Ministry of Law and Human Rights.

\subsection{Strengthening Synergies between Policy and Regulation}

Another crucial problem that needs to be handled is the disharmony between policymaking and regulatory-making to implement policies and ensure the harmony between the central and regional government as well as business and civil society interest. For example, the case between Investment Act of 2007 with Government Regulation No. 1 of 2007 concerning Income Tax Facilities for Investment in Certain Business and/or in Certain Regions. Art 1 (1) Investment Act of 2007 states that: "Investment is all forms of investment activities, both by foreign investors to do business in the territory of the Republic of Indonesia." Government Regulation No 1 of 2007, implementing Investment Act of 2007 states that: "Investment is in the form of tangible fixed assets that are used for main business activities, both for new investment and expansion of existing businesses." the two regulations has different meaning, where Investment Act of 2007 defines Investment as an activity and the Government Regulation No 1 of 2007 defines Investment as in the form of tangible fixed assets. This inconsistency will cause difficulties during the implementation.

Another case occurred between Art 22 (1) Investment Act of 2007 with Art 29 the Principles of Agrarian Provisions Act of 1960. In Art 22 (1) Investment Act of 2007 stated that: "Land Use Rights can be granted in the amount of 95 (ninety five) years by being granted and extended in advance at the same time for 60 (sixty) years and can be renewed for 35 (thirty five) years." Whereas Art 29 the Principles of Agrarian Provisions Act of 1960 stipulates that: "(1) The right to operate is granted for a 
maximum period of 25 (twenty five) years; (2) For companies that require a longer period of time, a right to use can be granted for a maximum period of 35 (thirty five) years; (3) At the request of the right holder and bearing in mind the condition of his company, the period referred to in paragraphs (1) and (2) of this article can be extended for a maximum period of 25 (twenty five) years. The longer-term arrangement of the granting of land use rights (95 years at the most at Art 22 (1) Investment Act of 2007) than the regulation in the Principles of Agrarian Provisions Act of 1960 (no longer than 60 years) is intended to increase Indonesia's competitiveness in the investment sector. These regulations could raise $s$ the disharmony of regulations and surely will induce problems in its implementation.

The above description shows that there are indications of a lack of understanding of government administrators of the differences and relationships between policies and regulations. The capacity of legal drafter in understanding policies, which will be the core substance of regulation, will considerably determine the quality of the resulting regulations. In the current situation, legal drafters are lack of capacity to understand the policies. Therefore, when analyzing the draft, they only focus on the technical problem, not the policy or its philosophy. ${ }^{20}$ This, of course, potentially leads to problematic regulations and causes new problems in the implementation. ${ }^{21}$ Thomas $\mathrm{R}$. Dye describes policy as everything that is chosen by the government to do something or not do something. ${ }^{22}$ According to Art 1 (2) of Law and Regulation Procedure Act of 2011 determines that Law and Regulation are contain generally binding legal norms and are formed or established by state institutions or authorized officials through the procedures stipulated in Law and Regulation. In other words, regulation is a formal form of government policy so that it can be implemented in the community. However, government policies do not have to always be converted into regulations. The difference between policies and regulations is as follows:

Table.1. Comparison between Policy and Regulation

\begin{tabular}{ll}
\hline Policy & Regulation \\
\hline $\begin{array}{l}\text { Choice of action among a number } \\
\text { of alternative actions. }\end{array}$ & Operational instruments for selected actions. \\
$\begin{array}{l}\text { Selected policies do not have to/ } \\
\text { always become a regulatory norm. }\end{array}$ & Regulation contains policy as substance. \\
& $\begin{array}{l}\text { Bound to the norms of the National Regulatory } \\
\text { Free Norm. }\end{array}$ \\
& $\begin{array}{l}\text { System, e.g. structure of regulation (there must } \\
\text { be no norm conflicts), must be consistent and } \\
\text { harmonious with other norms, etc. } \\
\\
\text { Need to control from aspects of policy } \\
\text { planning, coordination, monitoring, and } \\
\text { evaluation. }\end{array}$ \\
\hline
\end{tabular}

\footnotetext{
20 Bădescu, M. (2018). Legislative Inflation: an Important Cause of The Dysfunctions Existing in Contemporary Public Administration. Juridical Tribune, 8 (2), p. 357-369.

21 Sulmane, D. (2011). Legislative Inflation: an Analysis of The Phenomenon in Contemporary Legal Discourse. Baltic Journal of Law \& Politics, 4 (2), p. 78-101.

${ }^{22}$ Dye, T. R. (2016). Understanding Public Policy. Pearson, p. 411.
} 
Therefore, strengthening the capacity of policymakers and regulatory makers is a necessity that must get an extensive focus, considering that policy formulators and regulatory designers need to have the ability to analyze and harmonize these policies, of course, in-depth knowledge of the policies outlined and will be operationalized with these regulations is needed. ${ }^{23}$ In addition, increasing appreciation of the process is also a form of strengthening the capacity of policymakers and legal drafter. This can be done by organizing coordinating meetings between ministries/agencies. Capacity building can also be increased by empowering the implementation of public consultations, or what Law and Regulation Procedure Act of 2011 calls community participation. Lothar Gundling stated several reasons concerning the need for community participation in policy making, including, first, providing information on legal needs sociologically to the government, second, increasing people's willingness to obey state policies, third, providing guaranteed legal protection, fourth, democratic decision making. ${ }^{24}$ But until now, public consultations often disobey by legal drafter and just to fulfill provisions of Art 96 Law and Regulation Procedure Act of 2011. ${ }^{25}$

\subsection{Other Optional Policies}

There are many policies to adopt for the regulatory reform agenda in Indonesia, including omnibus methods which become popular legal issue since the government has drafted and discussed bill on job creation with the House of Representatives (the DPR). At the most basic level, omnibus law, known as omnibus bill under common law system, is solely packages of budget measures and policy changes. Started as a structural and organizational tool, it was originally a way for lawmakers to bundle similar proposals at once. ${ }^{26}$ Just like a regular law, this method is formal proposals to change laws with broad topics. Take the omnibus methods on tax as an example: It may include changes on everything from income, corporate, and sales taxes, but all of those issues can fit under comprehensive multisectoral aspect of taxes. But many legislative observers stated that the implementation has gotten out of control, with omnibus methods now encompassing so many issues that a single omnibus bill can span hundreds or even thousands of pages, often drafted in mere hours on short deadlines. ${ }^{27}$

Second optional policy is by guillotine approach, this method is an orderly, systematic, transparent, rapid and low-cost means of counting and then rapidly reviewing a large number of regulations against clear scientific criteria for good regulation, and eliminating those that are no longer needed. ${ }^{28}$ It results in economically-significant regulatory cost reductions for businesses, either on a government-wide scale or targeted at specific problem areas such as licenses or sectors. Extensive stakeholder participation helps to ensure that the reviews are realistic and factual. Its core principle is that any regulation that is not justified as legal and necessary for government policy

\footnotetext{
${ }^{23}$ Sadiawati, D. (2015). Strategi Nasional Reformasi Regulasi...Op. Cit, p. 37.

${ }^{24}$ Gundling, L. (1980). Public Participannt in Environmental Decision Making, dalam Trends in Environmental Policy and Law. IUCN Gland, p. 11.

${ }^{25}$ Sadiawati, D. (2015). Strategi Nasional Reformasi Regulasi...Op. Cit, p. 38.

${ }^{26}$ Massicotte, L. (2013) O.mnibus Bills in Theory and Practice. Parliamentary Rev, 13 (1),p. 14-15.

${ }^{27}$ Dodek, A, M. (2017). Omnibus Bills: Constitutional Constraints and Legislative Liberations. Ottawa Law Review, 48 (1), p. 16-17.

28 Jacobs, S. (2005). Bold and Sustainable Regulatory Reform: The Regulatory Guillotine in Three Transition and Developing Countries. World Bank Conference Reforming the Business Environment: From Assessing Problems to Measuring Results, p. 3-4.
} 
in a market economy will be eliminated. Any regulation that is legal and needed but not business-friendly will be simplified to the extent possible. The guillotine must have strong political leadership at the center of government. It is operated by a small, capable reform unit at the center of government set up especially for the guillotine. ${ }^{29}$

Third optional policy is "one-in, two-out" rule which has success in UK which described as for every one new regulation issued, at least two prior regulations be identified for elimination and that the cost of planned regulations be prudently managed and controlled through a budgeting process. UK has implemented this policy since 2010, first adopting a "one-in, one-out" rule whereby no new regulation is brought in without other regulation being cut by a greater amount., then a "one-in, two-out" rule and now a "one-in, three-out" variant. ${ }^{30}$

Forth optional policy is using the red tape challenge which aimed to reduce "cost to business" by removing regulatory burdens unless they could be justified. ${ }^{31}$ The Red Tape Challenge was run by the UK government between 2011 and 2014. It was designed to crowdsource the views from businesses, organizations and the public on which regulations should be improved, kept or scrapped. ${ }^{32}$

Fifth optional policy by including specific clause so that the regulation can correct itself in case there is a problem. Those clauses are, a review clause which provide review process after specified period since its enactment, a sunset clause which provide periodic review of the regulation, and, finally but not least, the temporary legislation clause which set the active period of the regulation in advance. ${ }^{33}$

Sixth optional policy is by rulemaking moratorium. This method is to moratorium or suspension of an activity or a law. Kathryn A. Watts called this method as Regulatory moratoria, which are also referred to as regulatory "suspensions" or "freezes," stem from legislative or executive action, and they aim to halt or suspend rulemaking activity for a specified period of time. ${ }^{34}$ In a legal context, it may refer to the temporary suspension of a law to allow a legal challenge to be carried out. ${ }^{35}$

\section{Conclusion}

This article is intended to outline the best policies in terms of regulatory reform, especially in this case in Indonesia. The proposed policies among other are simplification of regulations, reconceptualization of rule-making power, and strengthening synergies between policy and regulation. Lawmaker institution shall create database of legislation and regulation which are integrated and systematic. The

\footnotetext{
29 Jacobs S. (2005). The Regulatory Guillotine Strategy: Preparing the Business Environment in Croatia for Competitiveness in Europe. USAID, p. 5.

${ }^{30}$ Farrel, J. (2015), Better regulation in the UK, Paper Presentation on 2015

31 Lodge, M \& Wegrich, K. (2012). The 'Californication' of Government? Crowdsourcing and the Red Tape Challenge. Centre for Analysis of Risk and Regulation, p 9-10.

32 Ibid, p. 11.

${ }^{33}$ Shimada, Y (2017). Strategy and Regulatory Reform Practices in Japan: Harmonization of Central and Local Regulations in The Era of Local Autonomy. Proceeding on National Conference of Constitutional and Adminsistrative Law Academician, p. 444-446.

${ }^{34}$ Watts, K. A. (2012). Regulatory Moratoria. Duke Law Journal, 61 (2), p. 1885.

${ }^{35}$ O'Connel, A. J. (2015). Agency Rulemaking and Political Transitions. Northwestern University Law Review, 105 (2), p. 448.
} 
technology would facilitate information especially to find regulation that (1) conflict, (2) inconsistency, (3) multiple interpretations, (4) not operational reconceptualization of rule-making power is carried out by reformulating the authority of rule-making power, so it will be reducing intention to make unnecessary regulations. Strengthening synergy between policy and regulation is carried out by synchronization between policy and regulation drafting. In addition to the policies referred to, other legal policy options such as the omnibus methods will carry out massive deregulation by using one law only. Other policy options such as guillotine approach which success in Croatia, the red tape challenge or one in, one out, one in two out, and one in three out rule that are successfully implemented in the UK, or even apply specific clauses such as the review clause, the sunset clause or temporary legislation, and rulemaking moratorium are some alternative policy that could be useful in the future experiment of regulatory reform in Indonesia.

In the end, it is expect that there must be some reformation between actual practice and long term frameworks on regulation making process and regulation itself. That is because effective regulation is not just predicated on technical information-capturing capabilities (and the experience) of the regulator. It also depends on the involvement of civil society in the regulatory process. By ensuring broad participation, regulatory mechanism should not be able to deliver technically efficient and economically sound decisions, but to effectively resolve legitimate social conflicts, consistent with the public interest.

\section{Acknowledgments}

We would like to say thanks to Constitution, Law and Regulation Analysis Center University of Muhammadiyah Jakarta for supporting this article.

\section{References}

Books:

Anggono, B. D. (2014). Perkembangan Pembentukan Undang-Undang di Indonesia. Konstitusi Press.

Chandranegara, I.S. (2019). Kemerdekaan Kekuasaan Kehakiman Pasca Transisi Politik. Radjawali Press.

Dye, T. R. (2016). Understanding Public Policy. Pearson.

Ferguson, T. (1999). The Third World and Decision-Making in International Monetary Fund;The Quest for Full and Effective Participation. London Printer.

Gundling, L. (1980). Public Participannt in Environmental Decision Making, dalam Trends in Environmental Policy and law. IUCN Gland.

Ham, C. \& Hill, M. (1999). The Policy Process in the Modern Capitalist State. The Harvester Press.

Hartono, S. (2014). Analisis dan Evaluasi Peraturan Kolonial (Hindia Belanda dan Kependudukan Jepang). Ministry of Law and Human Rights. 
Heilmann, D., Ekatjahjana, W. \& Hauerstein, K. (2019). Regulatory Reform in Indonesia A Legal Perspective. Hanns Seidel Foundation Cooperation with The Ministry of Law and Human Rights Directorate General of Legislation.

Indrati, M. F. (2008). Compendium Report Concerning Legislation. Ministry of Law and Human Rights.

Jacobs, S. (2005). The Regulatory Guillotine Strategy: Preparing the Business Environment in Croatia for Competitiveness in Europe. USAID.

Lodge, M \& Wegrich, K. (2012). The 'Californication' of Government? Crowdsourcing and the Red Tape Challenge. Centre for Analysis of Risk and Regulation.

Marušić, A. and Radulović, B. (2011). Regulatory Impact Analysis (RIA) Manual. USAID.

Redi, A \& Chandranegara, I.S (2020). Omnibus Law: Diskursus Pengadopsiannya Ke Dalam Sistem Perundang-Undangan Nasional. Radjawali Press.

Sadiawati, D. (2015). Strategi Nasional Reformasi Regulasi: Mewujudkan Regulasi yang Tertib dan Sederhana. Kementerian Perencanaan dan Pembangunan Nasional/ Bappenas.

Seidman, A, Seidman, R., \& Abeyserkere, N. (2002). Drafting the Legislation on Changing Democratic Communities. Elips Department of Justice.

Snyder, R. C. et.al. (1998). Foreign Policy Decision-Making: An Approach to Study International Politics. The Free Pres.

\section{Journal Articles:}

Bădescu, M. (2018). Legislative Inflation: an Important Cause of The Dysfunctions Existing in Contemporary Public Administration. Juridical Tribune, 8(2), 357-369.

Chandranegara, I.S. (2016). Purifikasi Konstitusional Sumber Daya Air Indonesia. Rechtsvinding, 5(3), 359-379.

Dodek, A, M. (2017). Omnibus Bills: Constitutional Constraints and Legislative Liberations. Ottawa Law Review, 48(1), 2017, 1-21.

Hartono, D. \& Hardiwinoto, S. (2018). Legal Perspective on Asean Economic Community. Diponegoro Law Rev, 3(2), 199-222.

Malau, M. T. (2014). Legal Aspects of Government Regulations and Policies Facing Regional Economic Liberalization: ASEAN Economic Community 2015. Rechtsvinding, 3(2), 163-182.

Massicotte, L. (2013). Omnibus Bills in Theory and Practice. Parliamentary Rev, 13(1), 14-15.

O'Connel, A. J. (2015). Agency Rulemaking And Political Transitions. Northwestern University Law Review, 105(2), 434-469.

Šulmane, D. (2011). Legislative Inflation: an Analysis of The Phenomenon in Contemporary Legal Discourse. Baltic Journal of Law \& Politics, 4(2), 78-101. 
Suska. (2012). Principles of Regulatory Impact Assessment in the Process of Drafting Legislation in Accordance with Law No 12 of 2011. Constitution Journal, 9(2), 358-279.

Susskind, R. (2010). Legal Informatics: a Personal Appraisal of Context and Progress. European Journal of Law and Technology, 1(1), 88-110.

Watts, K. A. (2012). Regulatory Moratoria. Duke Law Journal, 61(2), 1878-1891.

\section{Conference Proceeding:}

Chandranegara, I.S. (2017). Menemukan Formulasi Diet Regulasi. National Conference of Constitutional and Administrative Law Academician, 208-211.

Farrel, J. (2015). Better Regulation in the UK, Paper Presentation on 2015.

Jacobs, S. (2005). Bold and Sustainable Regulatory Reform: The Regulatory Guillotine in Three Transition and Developing Countries. World Bank Conference Reforming the Business Environment: From Assessing Problems to Measuring Results, 3-4.

Setiadi, W. (2020). Simplifikasi Regulasi Melalui Pendekatan Omnibus Law: Suatu Keniscayaan. Studium Generale on Dies Natalis Universitas Pembangunan Nasional "Veteran" Jakarta, 1-14.

Shimada, Y. (2017). Strategy and Regulatory Reform Practices in Japan: Harmonization of Central and Local Regulations in The Era of Local Autonomy. National Conference of Constitutional and Adminsistrative Law Academician, 444-446.

\section{Magazine or News Paper:}

Djamil. N, Half-hearted Regulatory Reform, Seputar Indonesia, 12 ${ }^{\text {th }}$ November 2015.

Isra, S. (2017). Streamlining Regulation, Kompas.

\section{Regulations:}

Law No 5 of 1960 Concerning Land, Supplementary State Gazette No 2043.

Law No12 of 2011 Concerning Legislation and Regulation Making, State Gazette of 2011 No 82, , Supplementary State Gazette No 5234.

Law No 23 of 2014 Concerning Regional Government, State Gazette of 2014 No 244, Supplementary State Gazette No 5587.

Law No 36 of 2009 Concerning Health, Supplementary State Gazette No 5063.

Law No 18 of 2014 Concerning Mental Health, State Gazette of 2014 No 185

Law No 25 of 2007 Concerning Investment, State Gazette 2007 No 67, Supplementary State Gazette No 4724.

Government Regulation No 1 of 2007 Concerning Income Tax Facilities for Investment in Certain Business Fields and/or in Certain Regions, Supplementary State Gazette No 4675.

Ministry of Fisheries Regulation No 2 of 2015 Concerning Prohibition of Using Cantrang as Fishing Equipment, State Gazette of 2015 No 31. 
JURNAL MEDIA HUKUM, 27(1), 55-67

\section{Court Decisions:}

Constitutional Court Decision No 2-3/PUU-V/2007. 